\title{
ИСПОЛЬЗОВАНИЕ СРЕДСТВ ФИТНЕСА ПРИ ПОДГОТОВКЕ К ВЫПОЛНЕНИЮ НОРМ КОМПЛЕКСА ГТО (НА ОСНОВЕ УЧЕТА ПУЛЬСОВЫХ КРИВЫХ УПРАЖНЕНИЙ)
}

\author{
Серова Татьяна Васильевна, \\ старший преподаватель кафедры «Физическая культура», \\ Санкт-Петербургский Северо-Западный \\ медицинский университет им. И.И. Мечникова, \\ Россия, г. Санкт-Петербург; \\ Люйк Людмила Владимировна, \\ кандидат педагогических наук, доиент, \\ дочент кафедры «Физическая культура и адаптачия», \\ Санкт-Петербургский Политехнический университет Петра Великого, \\ Россия, г. Санкт-Петербург.
}

Аннотация: Возрождение комплекса ГТО направлено на решение проблемы укрепления здоровья, повыпения уровня физической подготовленности населения, в том числе и студенческой молодежи. Статья посвящена поиску путей успешной реализаџии комплекса. Используются новые формы двигательных действий, в основе которых лежит функциональное соответствие нормативам комплекса ГТО.

Ключевые слова: физическая подготовленность, комплекс ГТО, фитнес, компьютерные технологии, пульсовая кривая.

Annotation: The revival of the TRP complex is aimed at solving the problem of health promotion, improving the level of physical fitness of the population, including students. The article is dedicated to finding ways to successfully implement the complex. New forms of motor actions are used, which are based on functional compliance with the standards of the GTO complex.

Keywords: physical fitness GTO complex, fitness, computer technologies, pulse curve.

Актуальность. В целях создания эффективной системы физического воспитания, направленной на укрепление здоровья населения, с 1 сентября 
2014 г. в Российской Федерации введен в действие Всероссийский физкультурно-спортивный комплекс "Готов к труду и обороне" (ГТО). Анализ нормативно-правовой документации по исследуемому вопросу позволил выделить и условно определить 4 этапа существования комплекса ГТО. Период с 2013 года по настоящее время выделяется как «Этап возрождения ГТО» [1]. Внедрение нового комплекса требует поиска наиболее эффективных форм и методов в практической работе образовательных учреждений.

Традиционные занятия по физической культуре в образовательных учреждениях на сегодняшний день являются малоэффективными для оздоровления, для приобщения к здоровому образу жизни молодежи, не удовлетворяют их потребностей. Одним из путей решения этой проблемы, является внедрение фитнеса в систему физического воспитания подрастающего поколения [2].

Проблема. Проблема совершенствования физического воспитания молодёжи на основе внедрения средств фитнеса имеет следующие противоречия:

- между введением нормативов комплекса ГТО и уровнем физической подготовленности молодежи;

- между уровнем физической подготовленности, здоровьем подрастающего поколения и недостаточной научно-обоснованной разработанностью подходов повышения эффективности физического воспитания;

- между «традиционной методикой подготовки» к выполнению норм ГТО в форме «натаскивания» на результат и необходимостью разнообразия средств и методов для повышения уровня физической подготовленности подрастающего поколения (включая студенческую молодежь).

Цель исследования. Научно обосновать эффективность использования средств фитнеса (с учетом пульсовых кривых упражнений) на занятиях физической культурой в вузе для повышения уровня физической 
подготовленности студенток и успешной физической подготовки к выполнению норм комплекса ГТО.

Основные методы исследования: тестирование и педагогический эксперимент. Тестирование проводилось в комплексе с компьютерной технологией Polar Team 2, позволяющей записывать и контролировать ЧСС (частота сердечных сокращений) в режиме реального времени одновременно у 10 и более занимающихся.

В первой части эксперимента были проведены измерения по видам двигательной деятельности, (которые напрямую или косвенно включены в перечень комплекса ГТО) для разного пола и возраста. Нормативы были разделены на упражнения силового, скоростно-силового и аэробного характера (таблица 1).

Таблица 1

Виды направленности нормативов комплекса ГТО

\begin{tabular}{|c|c|}
\hline Направленность & Упражнения \\
\hline \multirow{4}{*}{ Силовая } & 1.Сгибание и разгибание рук в упоре, лежа на полу \\
\hline & 2.Подтягивание на высокой перекладине \\
\hline & 3.Подтягивание на тренажере \\
\hline & 4. Сгибание и разгибание рук с гантелями, стоя (бицепс) \\
\hline \multirow{4}{*}{ Скоростно-силовая } & 1.Поднимание туловища из положения, лежа на спине за 60 с. \\
\hline & 2. Прыжки на скакалке \\
\hline & 3. Бег (4х25м) или 100 м \\
\hline & 4. Приседания за 45 с \\
\hline \multirow{3}{*}{ Аэробная } & 1.Бег 6 и 7 минут \\
\hline & 2. Ходьба по беговой дорожке 6 мин. \\
\hline & 3. Работа на велотренажере 6 мин. \\
\hline
\end{tabular}

Результаты исследования. В течение исследования были получены

- характерные виды пульсовых кривых для каждого из перечисленных выше двигательных действий;

- определены оптимальные величины ЧСС испытуемых (в зависимости от их пола, возраста, веса), а также энергозатраты. 
Исследование пульсовых кривых позволило предположить, что если в процессе фитнес-занятий воспроизводить подобные формы функциональной реакции организма занимающихся, (выполняя модификации упражнений аналогичных по методической направленности целевым нормативам), то это позволит успешнее подготовить студенток к выполнению норм комплекса ГТО.

Педагогический эксперимент и его результаты подтвердили настоящее предположение (таблица 2).

Таблица 2

Физическая подготовленность испытуемых контрольной и экспериментальной групп после эксперимента

\begin{tabular}{|c|c|c|c|c|c|}
\hline № & Tect & $\mathrm{n}$ & Группа & $\mathrm{M} \pm \mathrm{m}$ & $\mathrm{p}$ \\
\hline \multirow{2}{*}{1} & \multirow{2}{*}{ Степ-тест (уд/мин.),ЧСС } & 40 & КГ & $77.10 \pm 1.90$ & \multirow{2}{*}{$\leq 0,05$} \\
\hline & & 25 & $Э Г$ & $73.20 \pm 2.04$ & \\
\hline \multirow{2}{*}{2} & \multirow{2}{*}{ Поднимание туловища за 60 с. (кол-во) } & 40 & КГ & $33.40 \pm 1.43$ & $\leq 0,05$ \\
\hline & & 25 & ЭГ & $39.35 \pm 1.59$ & \\
\hline \multirow{2}{*}{3} & \multirow{2}{*}{$\begin{array}{l}\text { Сгибание-разгибание рук в упоре, стоя на } \\
\text { коленях } 60 \text { с (кол-во) }\end{array}$} & 40 & КГ & $23.20 \pm 1.09$ & \multirow{2}{*}{$\leq 0,05$} \\
\hline & & 25 & $Э Г$ & $27.55 \pm 1.24$ & \\
\hline \multirow{2}{*}{4} & \multirow{2}{*}{ Наклон, стоя на скамейке (см) } & 40 & КГ & $10.49 \pm 1.69$ & \multirow{2}{*}{$\leq 0,05$} \\
\hline & & 25 & $Э Г$ & $13.05 \pm 1.78$ & \\
\hline \multirow{2}{*}{5} & \multirow{2}{*}{ Динамометрия (daN) } & 40 & КГ & $27.75 \pm 1.05$ & \multirow{2}{*}{$>0,05$} \\
\hline & & 25 & ЭГ & $27.70 \pm 1.43$ & \\
\hline \multirow{2}{*}{6} & \multirow{2}{*}{ Прыжки через скакалку за 30 с (кол-во) } & 40 & КГ & $64.00 \pm 1.63$ & \multirow{2}{*}{$\leq 0,05$} \\
\hline & & 25 & ЭГ & $67.75 \pm 1.72$ & \\
\hline \multirow{2}{*}{7} & \multirow{2}{*}{ Прыжок в длину с места (см) } & 40 & КГ & $168.03 \pm 2.10$ & \multirow{2}{*}{$\leq 0,05$} \\
\hline & & 25 & $Э Г$ & $173.3 \pm 2,14$ & \\
\hline \multirow{2}{*}{8} & \multirow{2}{*}{ Бег 100 м (c) } & 40 & КГ & $18.01 \pm 0.11$ & \multirow[b]{2}{*}{$\leq 0,05$} \\
\hline & & 25 & ЭГ & $17.18 \pm 0.13$ & \\
\hline \multirow{2}{*}{10} & \multirow{2}{*}{ Бег 1000 м (мин.) } & 40 & КГ & $4,98 \pm 0,11$ & \multirow{2}{*}{$\leq 0,05$} \\
\hline & & 25 & $Э Г$ & $4,47 \pm 0,17$ & \\
\hline
\end{tabular}

Таким образом, применение на занятиях физической культурой средств фитнеса, моделирующих параметры внутренней нагрузки упражнений комплекса ГТО (по пульсовым кривым), позволяет повысить уровень физической подготовленности занимающихся и обеспечить успешное выполнение норм комплекса ГТО. 


\section{Список литературы:}

1. Солодянников В.А., Серова Т.В., Люйк Л.В. Комплекс «Готов к труду и обороне» от возникновения к возрождению. Наука, образование, общество: актуальные вопросы и перспективы развития. Сб. науч. тр. Международной науч.-практ. конференции 30.09. 2015 г.: в 4 частях. Консалт», 2015 г. - С. 46-49 с.

2. Сайкина Е.Г. Фитнес в системе физической культуры / Е.Г. Сайкина // Известия РГПУ им. А. И. Герцена. 2008. -№ 68. -С. 182-190. 